\title{
BEHAVIOUR OF LOAD-BEARING COMPONENTS OF A CUSHIONED COMPOSITE PILED RAFT FOUNDATION UNDER AXIAL LOADING
}

\author{
V. J. SHARMA ${ }^{1 *}$, S. A. VASANVALA ${ }^{1}$, C. H. SOLANKI ${ }^{1}$
}

\begin{abstract}
In the last decade piled raft foundations have been widely used around the world as intermediate foundation systems between piles and rafts to control the settlement of foundations. However, when those piles are structurally connected to rafts, relatively high axial stresses develop in relatively small numbers of piles, which are often designed to fully mobilize their geotechnical capacities. To avoid a concentration of stress at the head of piles in a traditional piled raft foundation, the raft is disconnected from the piles, and a cushion is introduced between them. Also, to tackle an unfavourable soil profile for a piled raft foundation, the conventional piled raft has been modified into a cushioned composite piled raft foundation, where piles of different materials are used. In the current study the behavior of cushioned foundation components, which transfer the load from the structure to the subsoil, are analyzed in detail, i.e., the thickness of the raft, the length of a long pile and the modulus of a flexible pile.
\end{abstract}

\section{INTRODUCTION}

In a traditional foundation design, a shallow foundation is usually preferred to carry the load applied. If the load exceeds the shallow foundation's capacity or is inadequate, a piled foundation can be used with the assumption that the design loads will be completely carried by the piles. For buildings on thick soft soils in the southern part of Gujarat (India), many foundation types, ranging from shallow foundations on untreated or treated soils by various ground-improvement methods to deep foundations supported by different pile types, have been successfully used. However, shallow foundations generally undergo excessive settlement, and the piled foundations are usually used to carry large loads and are generally not cost effective, as the pile groups are designed to consider relatively higher safety factors and the main design criteria is the bearing capacity of the pile group. To minimize the cost and increase the bearing capacity of the foundation system, a pile-enhanced raft has been used most widely in Europe and Asia. The piled raft foundation is a recent design concept

\section{Address}

1 Applied Mechanics Department, Sardar Vallabhbhai National Institute of Technology, Gaurav Path, Ichchhanath, Surat, Gujarat 395007, India

* Corresponding author: nitk.vijay@gmail.com

\section{Key words}

- Cushion

- composite piled raft foundation,

- concentration of stress. that is viewed as one of the most effective methods to reduce the settlement of superstructures. In a traditional piled raft with a large number of piles, the piles are typically assumed to take all the load, and there is a margin for the pile to reach either its geotechnical bearing capacity or its structural collapse load. In contrast, when piles are considered as soil reinforcements or settlement reducers, the ultimate geotechnical capacity could be fully mobilized. In the actual application of a piled raft, the pile penetrates through the raft to form a rigid connection. When settlement-reducing piles are designed as structural components, a low safety factor can be applied to the geotechnical capacity of the piles, and the raft alone is adequate. However, when these piles are structurally connected to a raft, as they generally are, a high degree of axial stress may develop in a relatively small number of piles. Thus, the load-carrying capacity of these settlement- reducing piles may be governed by their structural capacity rather than by their geotechnical capacity as per Eslami et al. (2011).

Secondly, a favourable application of a piled raft occurs when the raft has an adequate loading capacity, but the settlement or differential 


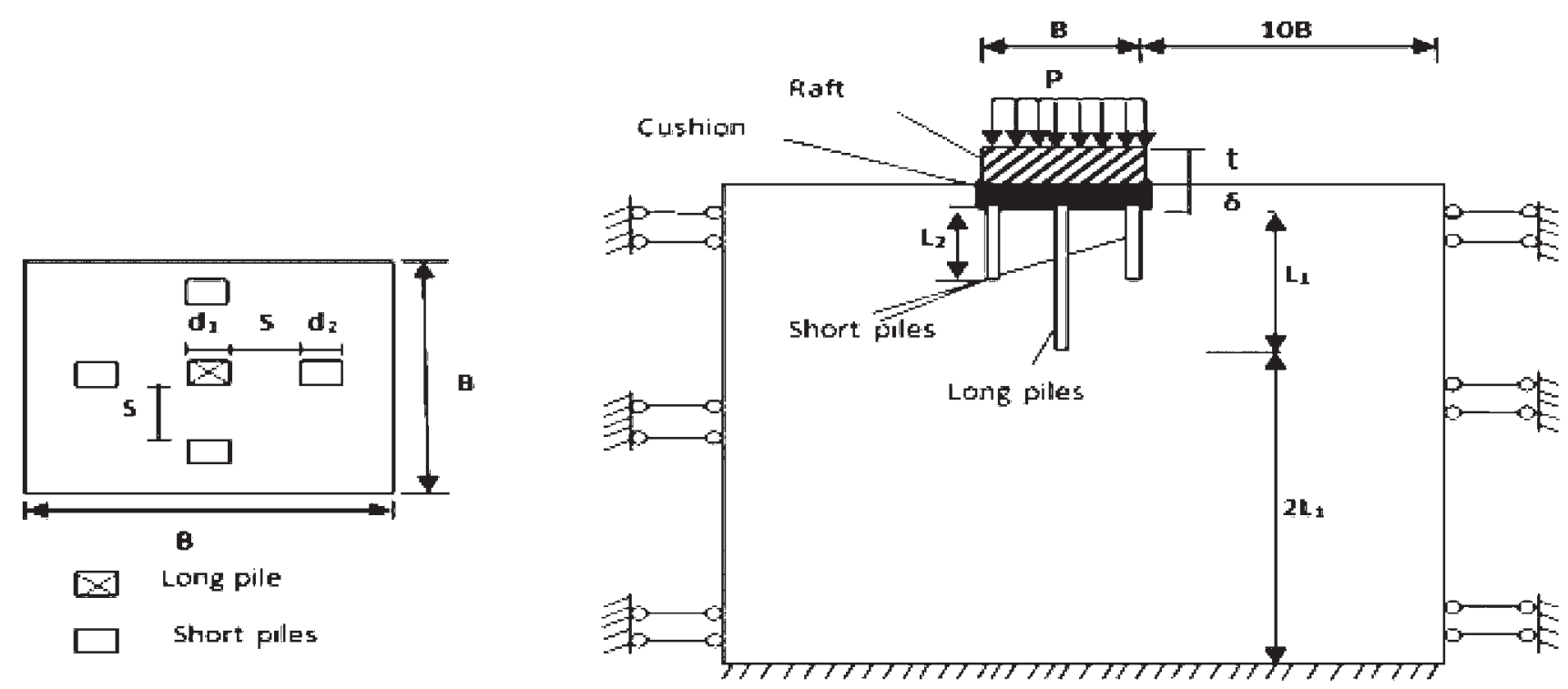

Fig. 1 Schematic diagram of cushioned composite piled raft foundation with boundary conditions.

settlement exceeds the allowable values. Conversely, unfavourable situations for a piled raft include soil profiles containing soft clays near the surface, soil profiles containing loose sand near the surface, soil profiles that are likely to undergo consolidation settlements, soft compressible layers at relatively shallow depths, and soil profiles that are likely to undergo swelling movements due to external causes as per Polous (2001). In these unfavourable situations, the raft might not be able to provide a significant loading capacity, or the long-term settlement of the compressible underlying layers might reduce the contribution of the raft to the long-term stiffness of the foundation. Since most of the economically developed cities in India are located near the coastal area, for example Mumbai, Surat, etc., the construction of buildings in these cities often meets with deep deposits of soft soil. Thus the concept of a piled raft foundation is modified (see Liang et al., 2001; Kaifu et al., 2009 and Zheng et al., 2008) to a composite piled raft foundation consisting of piles of different stiffnesses i.e., a long reinforced concrete pile embedded in a hard strata, whereas short sand-cement piles applied at a shallow depth to improve the bearing capacity of the upper soil and cushion the compacted coarse grain soil are incorporated between the raft and pile for mobilizing the bearing capacity of the subsoil and modifying the load transfer mechanism of the piles. The three-dimensional finite element method (FEM) was utilized as a numerical approach to investigate the factors that play an important role in the load transfer from the superstructure to the bottom subsoil. The parameters considered are the thickness of the raft, the length of the long rigid piles, and the modulus of the flexible piles. The analysis includes a study of the axial stresses along the piles, settlement, shear force distribution, and normalized contact pressure along the raft.

\section{NUMERICAL ANALYSIS MODEL}

Fig. 1 illustrates the composite piled raft foundation model considered in this study, which consists of a platform supported by a long RCC pile at its center and four shorter soil-cement piles along the edge of the raft surrounding the long RCC pile. In the analysis, the raft and piles are in an elastic state. The nonlinear behavior of the soil has been modelled with an elastic ideal plastic constitutive model with a Mohr Coulomb yield criterion. As mentioned by Baziar et al. (2009), this assumption is relatively applicable to piled raft foundation systems that are subjected to the conditions within the ranges of the service loads. The interaction between the piles and the soil is modelled with a modified Coulomb theory by defining the friction coefficient $\mu$ (Equation (1)). A limiting displacement of $5 \mathrm{~mm}$ was assumed for the full mobilization of the skin friction as suggested by Lee (2002).

$$
\mu=\tan (\delta)
$$

where the interface friction angle $\delta$ can be estimated using equation (2) based on Randolph et al. (1981).

$$
\delta=\tan ^{-1}\left(\sin \varphi^{\prime} x \cos \varphi^{\prime} /\left(1+\sin 2 \varphi^{\prime}\right)\right),
$$

where $\varphi$ ' is the effective internal soil friction angle.

The piles have been given as square sections for dividing the grid element conveniently. The length of the long and short piles was decided after a thorough study of the geological profile for the city of Surat (India) (SIR, 1995; SIR, 2009).

The pile dimensions and spacing and the overall foundation dimensions were typical values used in engineering practice. They are as follows: Long pile width $\mathrm{d}_{1}=0.45 \mathrm{~m}$, length $\mathrm{L}_{1}=15 \mathrm{~m}$; soil-cement piles width $\mathrm{d}_{2}=0.45 \mathrm{~m}$, length $\mathrm{L}_{2}=5.42 \mathrm{~m}$. The clearance between the adjacent piles was set at $0.45 \mathrm{~m}$. The spacing between the short piles was also $0.45 \mathrm{~m}$. The remaining dimensions are as follows: width of platform and cushion $B=6 d_{1}=2.70 \mathrm{~m}$, thickness of the platform $\mathrm{h}=0.5 \mathrm{~m}$, and thickness of the cushion $\delta=0.3 \mathrm{~m}$. The piles were assumed to have square sections for convenience in constructing the mesh. The size of the modelled domain and mesh was determined on the basis of trial calculations, during which the mesh was progressively refined and its boundaries extended until the stresses and deformations at the highly stressed zones around the piles and platform sufficiently stabilized. The results of the trial calculations showed that the bottom boundary should be set at a depth of $3 \mathrm{~L} 1\left(\mathrm{~L}_{1}\right.$ is the length of the RCC piles) from the pile heads, while the side boundaries should be located at a distance of 10B from the platform edge, where B is the width of the platform. The bottom boundary is treated as a fixed boundary, whereas the surrounding boundaries are to be treated as vertically sliding and horizontally restrained. A uniformly distributed load of $\mathrm{p}=100 \mathrm{kPa}$ is normally applied to the raft 

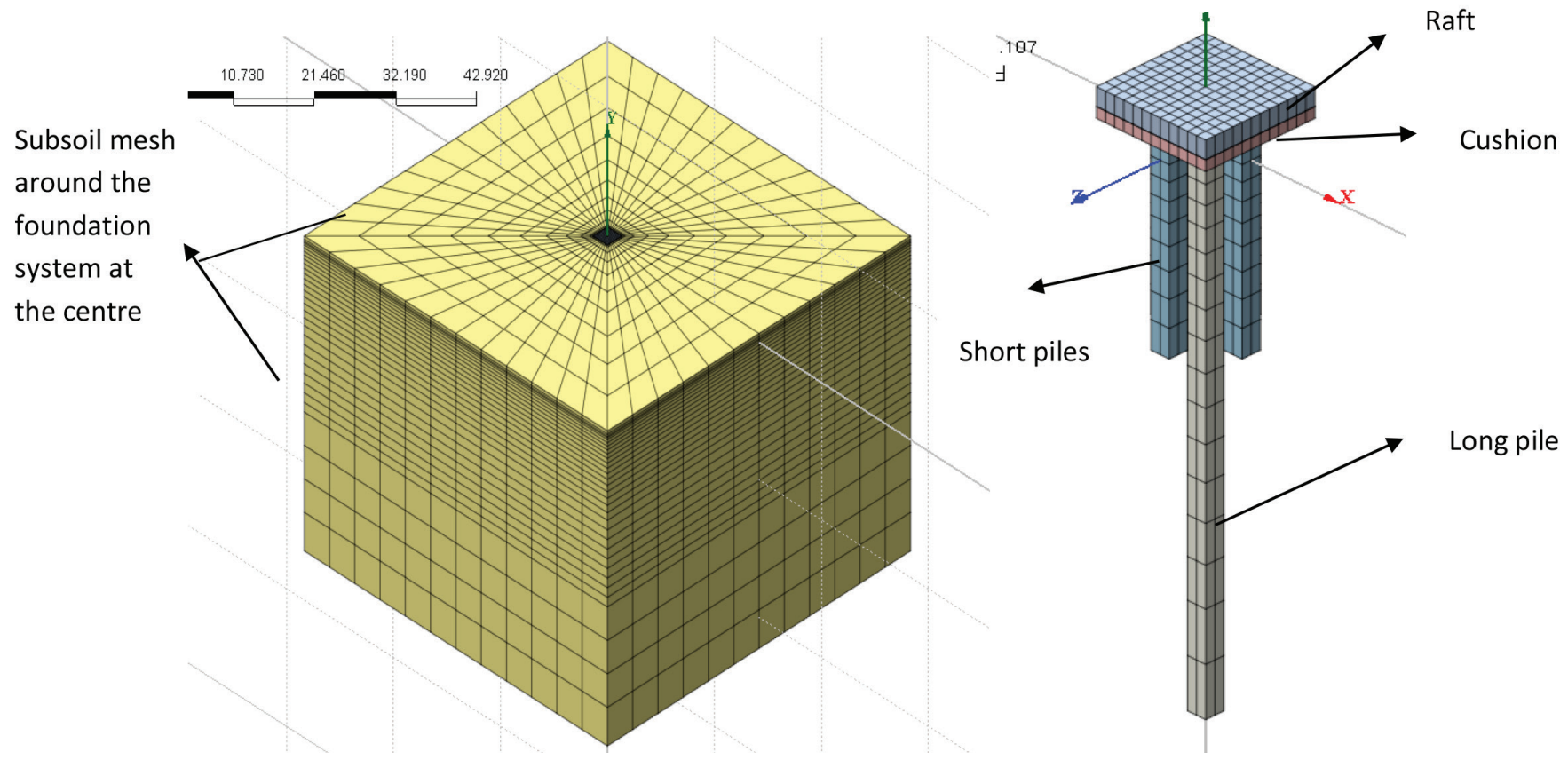

Fig. 2 Three-dimensional model of a composite piled raft foundation used for the analysis.

for a linear static analysis. The analytic method refers to the three-dimensional finite element method proposed by Ottaviani (1975).

The FEM analysis was carried out using the Midas GTS (2012 version 2.2) (Midas, 2012) by discretizing the platform, cushion, piles and soil geometry model into finite elements as shown in Fig. 2. In the present study, eight-node brick elements (SOLID) were employed. A maximum of 21,417 nodes and 19,968 elements were employed to represent the model analyzed. Previous studies have shown that eight-node brick elements can adequately describe the pile and cap behavior when a proper finite element mesh is used in the analysis. The elastic moduli and Poisson's ratios of long piles, short piles, subsoil and cushion are listed in Table 1.

\section{PERFORMANCE OF CUSHIONED COMPOSITE PILED RAFT FOUNDATION}

In practice, the long piles and raft are usually made of reinforced concrete with the elastic moduli nearly constant, so changing the elastic modulus of the rigid piles is rarely used to adjust the settlement. However the elastic modulus of the flexible piles could be managed as per the field requirements by varying the cement contents in the soil-cement column. Also, the thickness of the raft and length of the long piles can play an important role in adjusting the settlement of the whole foundation system. The raft's thickness, long pile length and short pile modulus are the channels through which the load from the superstructure is transferred to the surrounding and bottom subsoil. Thus in this paper, a parametric study is carried out to consider the thickness of the raft, the length of the long piles, and the modulus of the short piles to analyze the behavior of the cushioned composite piled raft foundation.

\subsection{Thickness of the raft}

In the calculations, $\delta=0.3, \mathrm{Em}=80 \mathrm{MPa}, \mathrm{E}_{\mathrm{lp}}=25000 \mathrm{MPa}$, Esp $=200 \mathrm{MPa}$, the thickness of the raft varies from $0.25 \mathrm{~m}$ to $2 \mathrm{~m}$, $\mathrm{L}_{1}$ length of long pile $=15 \mathrm{~m}, \mathrm{~L}_{2}=5.42 \mathrm{~m}$ is kept constant, and the other parameters are the same as the above.

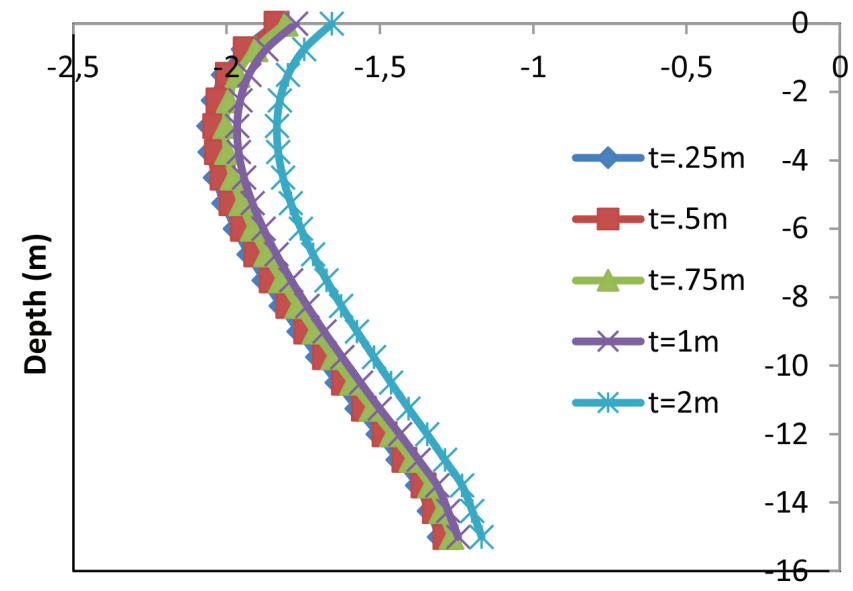

Axial stresses on the long pile (MPa)

Fig. 3 Comparison of the axial stress distributions along the depth of the long pile for varying thicknesses of the raft.

Tab. 1 Parameters of materials considered for the analysis.

\begin{tabular}{|c|c|c|c|c|c|}
\hline Material & Long piles & Short piles & Subsoil & Cushion & Raft \\
\hline Elastic modulus/MPa & $\mathrm{E}_{\mathrm{lp}}=25,000$ & $\mathrm{Esp}=60 \sim 2800$ & $\mathrm{E}_{\mathrm{s}}=5 \sim 50$ & $\mathrm{Em}=10 \sim 80$ & $\mathrm{E}_{\mathrm{c}}=3 \times 10^{4}$ \\
\hline Poisson's ratio & $\mu_{\mathrm{lp}}=0.2$ & $\mu_{\mathrm{sp}}=0.3$ & $\mu_{\mathrm{s}}=0.35$ & $\mu_{\mathrm{m}}=0.3$ & $\mu_{\mathrm{c}}=0.2$ \\
\hline
\end{tabular}


The graph in Fig. 3 shows the axial stress distribution along the long pile for varying thicknesses of the raft, i.e., $0.25 \mathrm{~m}, 0.5 \mathrm{~m}$, $0.75 \mathrm{~m}, 1 \mathrm{~m}$ and $2 \mathrm{~m}$. In all the cases the maximum axial stress was shifted from the head to a lower depth with the use of the cushion technique. As the thickness increases, the axial load-carrying capacity of the long pile slightly decreases with respect to each other in the case of $0.25 \mathrm{~m}, 0.5 \mathrm{~m}, 0.75 \mathrm{~m}$ and $1 \mathrm{~m}$ respectively; however, for the 2 $\mathrm{m}$ thick raft, the vertical load concentration on the long pile drastically reduces. Similarly, in the case of the short piles as seen in Fig.4, the concentration of the stress reduces with the increase in the thickness of the raft from $0.25 \mathrm{~m}$ to $2 \mathrm{~m}$; however, the reduction is noticeable for the $2 \mathrm{~m}$-thick raft, thus indicating that as the thickness increases, the load is chiefly carried by the raft itself.

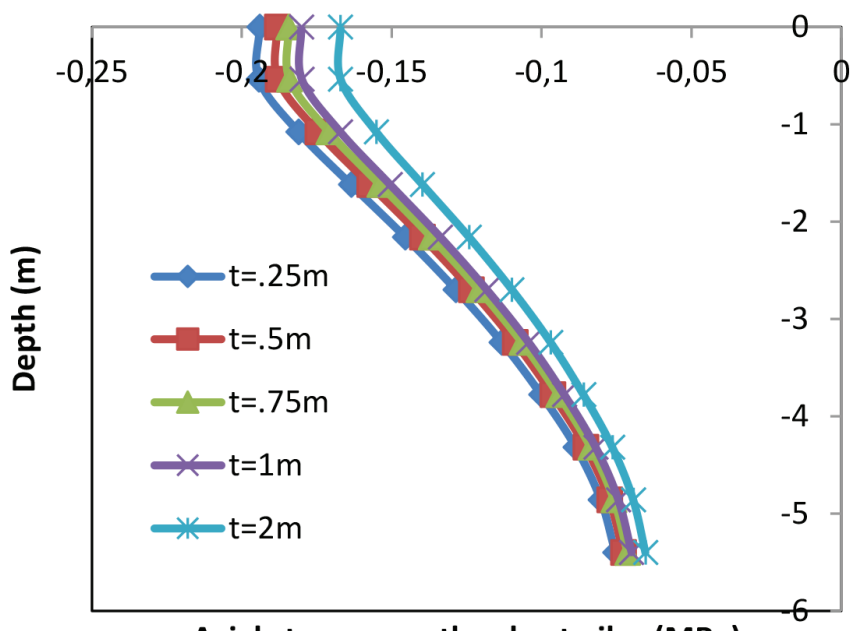

Axial stresses on the short piles (MPa)

Fig. 4 Comparison of the axial stress distributions along the depth of the short piles for varying thicknesses of the raft.

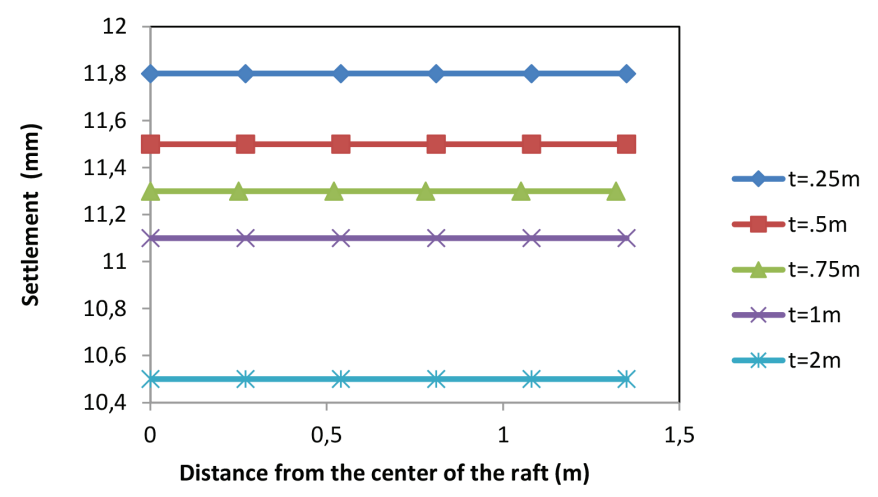

Fig. 5 Comparison of the settlement variations along the raft for varying thicknesses of the raft.

The graph shown in Fig. 5 shows a comparison of the settlement along the raft for different thicknesses of the raft, which vary from $0.25 \mathrm{~m}$ to $2 \mathrm{~m}$. It is clear that the settlement of the raft reduces with an increase in the thickness of the raft; thus a raft with a $2 \mathrm{~m}$ thickness shows less of a settlement compared with a raft with a $0.25 \mathrm{~m}$ thickness. With an increase in the raft's thickness the raft's stiffness increases; thus its load carrying capacity is enhanced, which in turn leads to a reduction in the settlement.

The graph in Fig. 6 shows a comparison of the shear force distribution along the raft for varying thicknesses of the raft, i.e., 0.25 $\mathrm{m}, 0.5 \mathrm{~m}, 0.75 \mathrm{~m}, 1 \mathrm{~m}$ and $2 \mathrm{~m}$ respectively. The graph shows that the

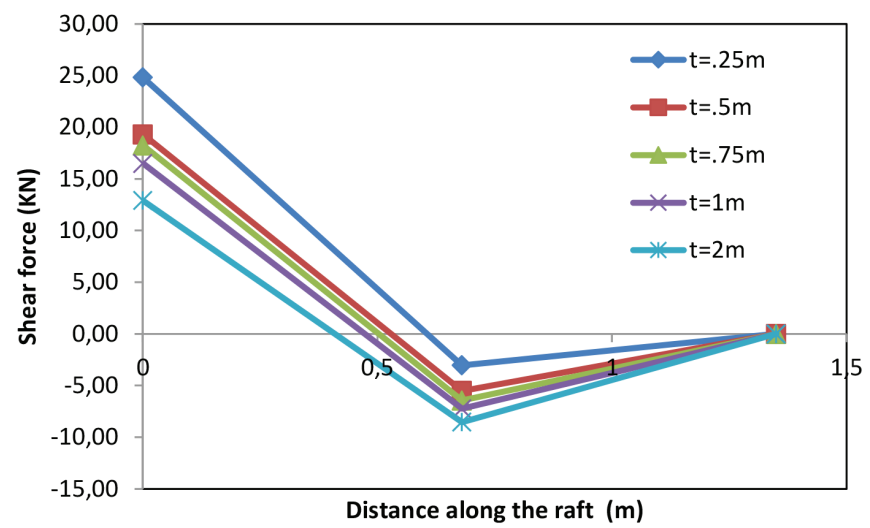

Fig. 6 Comparison of the shear force distributions along the raft for varying thicknesses of the raft.

shear force is at a minimum for a $2 \mathrm{~m}$ thick raft and reduces as the raft reduces its thickness from $0.25 \mathrm{~m}, 0.5 \mathrm{~m}, 0.75 \mathrm{~m}$ and $1 \mathrm{~m}$. It clear that the maximum shear force at the center of a raft reduces with an increase in the raft's thickness because the reaction developed beneath the raft reduces, as most of the load is carried by the raft itself and less is transferred beneath it.

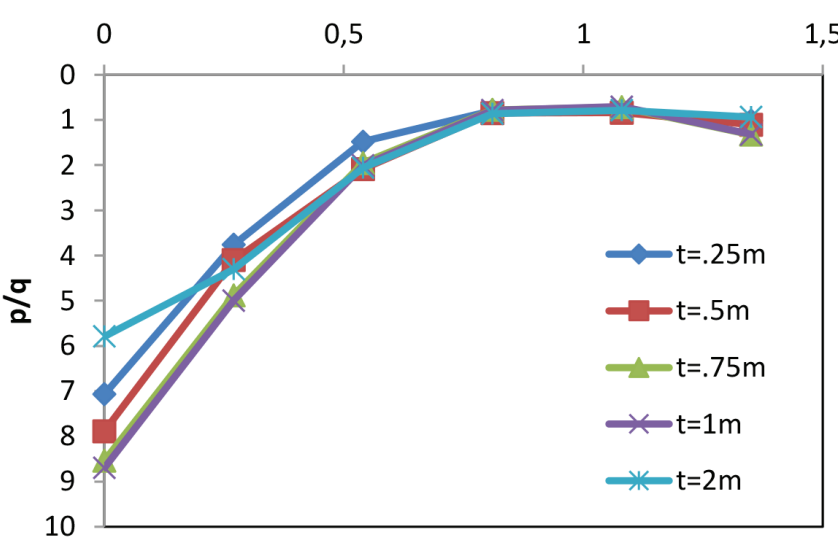

Distance from the center of the raft $(\mathrm{m})$

Fig. 7 Comparison of the normalized contact pressure along the raft for varying thicknesses of the raft.

The graph shown in Fig. 7 represents the normalized contact pressure along the raft for varying thicknesses of the raft, i.e., $0.25 \mathrm{~m}, 0.5$ $\mathrm{m}, 0.75 \mathrm{~m}, 1 \mathrm{~m}$ and $2 \mathrm{~m}$, respectively. It is clear that in all the cases the normalized contact pressure is at a maximum at the center and reduc-

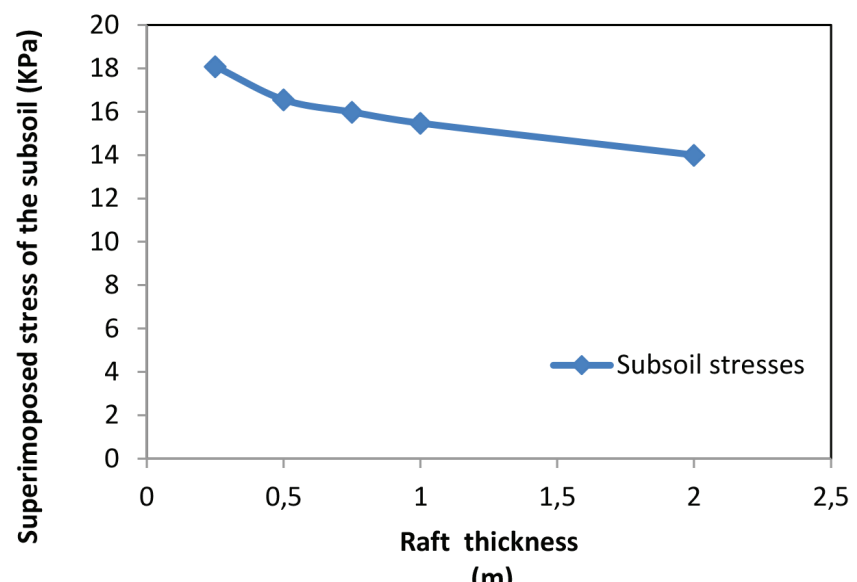

(m)

Fig. 8 Superimposed stresses of the subsoil for varying thicknesses of the raft. 
es towards the edge of the raft. Also, the p/q along the raft increases with an increase in the thickness of the raft; however, beyond a $1 \mathrm{~m}$ thick raft, the contact pressure decreases. This indicates that with an increase in the raft's thickness, the load is carried predominantly by the raft, thus increasing the load-carrying capacity of the raft.

The graph in Fig. 8 shows that as the thickness of the raft increases, the superimposed stress on the subsoil reduces; thus the load is mostly carried out by the raft itself.

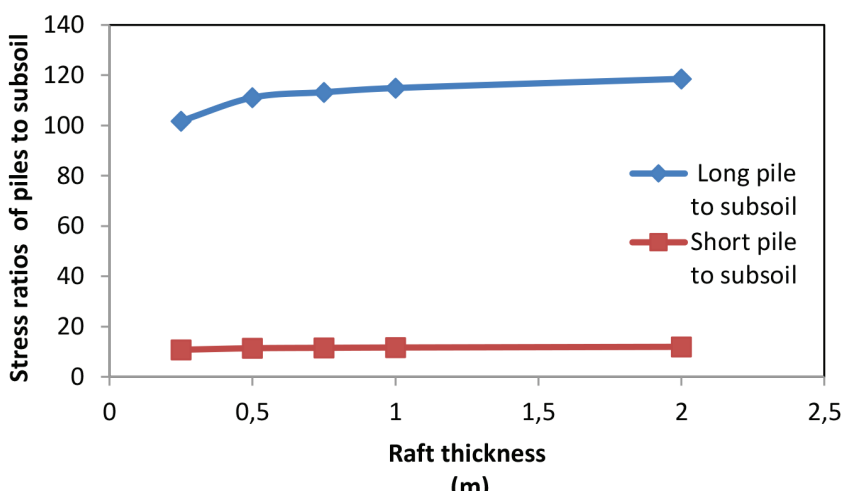

(m)

Fig. 9 Stress ratios of the piles to the subsoil for varying thicknesses of the raft.

As per Fig. 9, the ratio of the load carried by the long pile to the subsoil has slightly increased with the increase in the raft's thickness. The graph also shows that the short piles are also carrying some axial load, thus indicating that with the incorporation of the cushion, the load sharing has been evenly accomplished among the piles and subsoil.

\subsection{Length of the long pile}

In the calculations, $\delta=0.3 \mathrm{~m}, \mathrm{Em}=80 \mathrm{MPa}, \mathrm{E}_{\mathrm{lp}}=25000 \mathrm{MPa}$, $E s p=200 \mathrm{MPa}$, the $\mathrm{L}_{1}$ length of the long pile varies from $10-20 \mathrm{~m}$, $\mathrm{L}_{2}=5.42 \mathrm{~m}$ is kept constant, and the other parameters are the same as the above. The results for all the lengths of the long piles considering the axial stress along the short and long piles along with the settlement, axial stress, and normalized contact pressure for the raft, has been compared and is discussed thoroughly below.

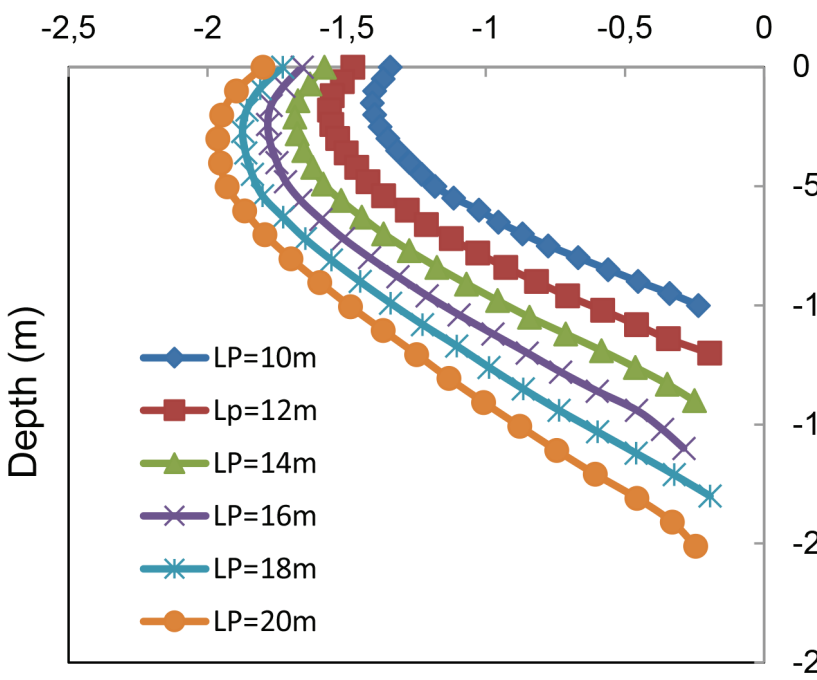

Axial stresses on the long piles (MPa)

Fig. 10 Comparison of the axial stress distributions along the depth of the long piles for varying lengths of the long pile.
Fig. 10 shows the axial stress distribution along the long pile for lengths varying from $10 \mathrm{~m}$ to $20 \mathrm{~m}$. In all the cases, it is observed that the concentration of the axial stress is shifted from the head to the lower depths; that occurs because the load undertaken by the subsoil increases under the adjustment of the cushion, and the displacements of the subsoil are larger than that of piles at a range of a certain depth along the pile shaft. Then, the negative friction is generated by the relatively larger settlement of the shallow subsoil. However, when the depth is lower than a certain depth, the displacements of the piles are larger than that of the subsoil with the further increasing of the depth, and the friction along the piles will become positive, with the axial stress of the piles decreasing with the depth again.

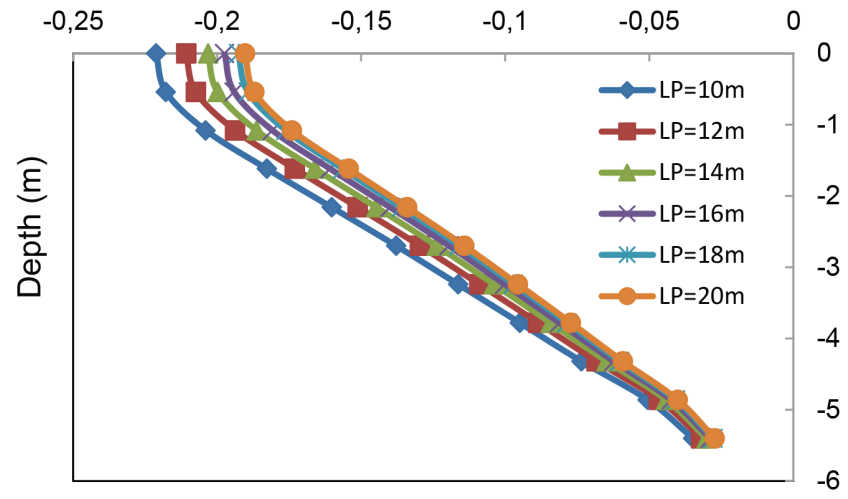

Axial stresses on the short piles (MPa)

Fig. 11 Comparison of the axial stress distributions along the depth of the short piles for varying lengths of the long pile.

The graph in Fig. 11 shows the axial stress distributions along the short piles for varying lengths of the long pile. It is clear that the axial stress is greater on the short piles compared to the long pile (Fig .10) for the same length of the long pile, i.e., $10 \mathrm{~m}$, thus indicating that with the application of the cushion, the load sharing can be evenly adjusted among the piles, thus making better use of the load-carrying capacity of the short piles.

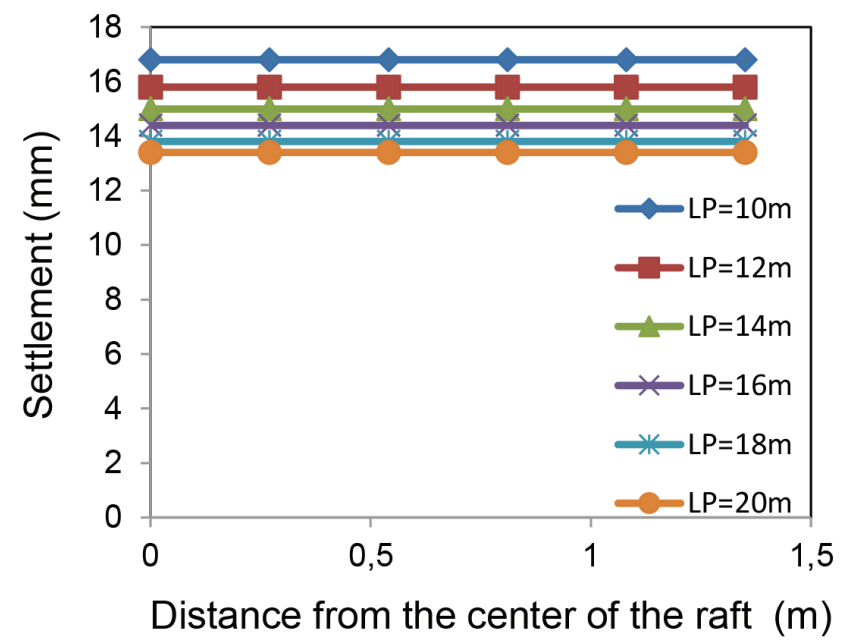

Fig. 12 Comparison of the settlement variations along the raft for various lengths of the long pile.

The graph in Fig. 12 shows a comparison of the settlements along the raft for different lengths of the long pile, varying from $10 \mathrm{~m}$ to $20 \mathrm{~m}$. It is clear that the settlement of the raft is at a maximum for a long pile of a $10 \mathrm{~m}$ length and a minimum for a $20 \mathrm{~m}$-long pile, thus 
the settlement of the raft can be reduced using a longer pile; however, there is an optimum depth of the long pile, after which the reduction in the settlement of the raft is negligible. With an increase in the long pile's length, the skin friction along the pile raft increases, leading to a reduction in the raft's settlement; however, beyond a certain depth, the effect of the friction become constant and has only a minor influence on the raft's settlement.

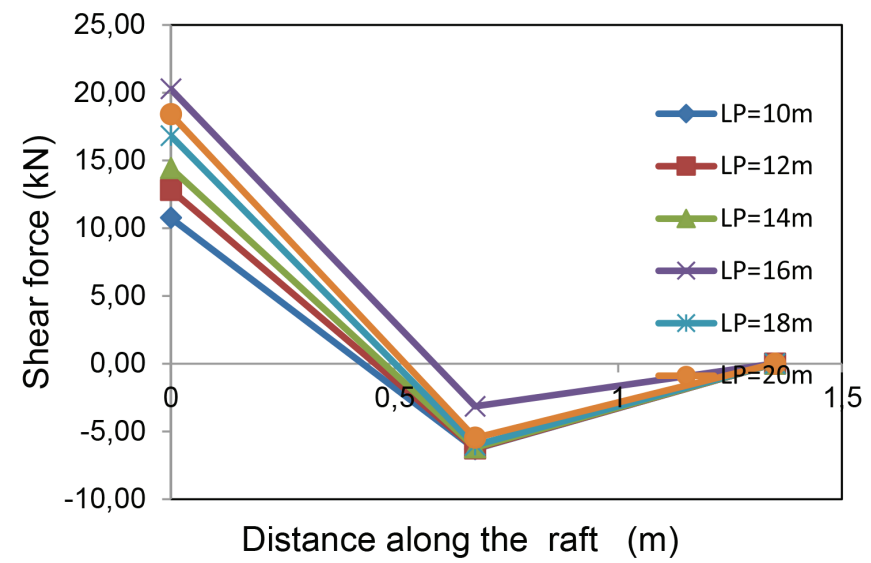

Fig. 13 Comparison of the shear force distributions along the raft for various lengths of the long pile.

The graph in Fig. 13 shows a comparison of the shear force distribution along the raft for various lengths of the long piles. The graph shows that the shear force is at a minimum for the lower length of a long pile and increases with an increase in the length of the long pile. The upward reactions that develop are mostly initially transferred to the raft from the surrounding subsoil; however, with an increase in the length of the pile, the load is mainly carried by the long pile and transferred to the strata below; thus the trends are obtained in this fashion.

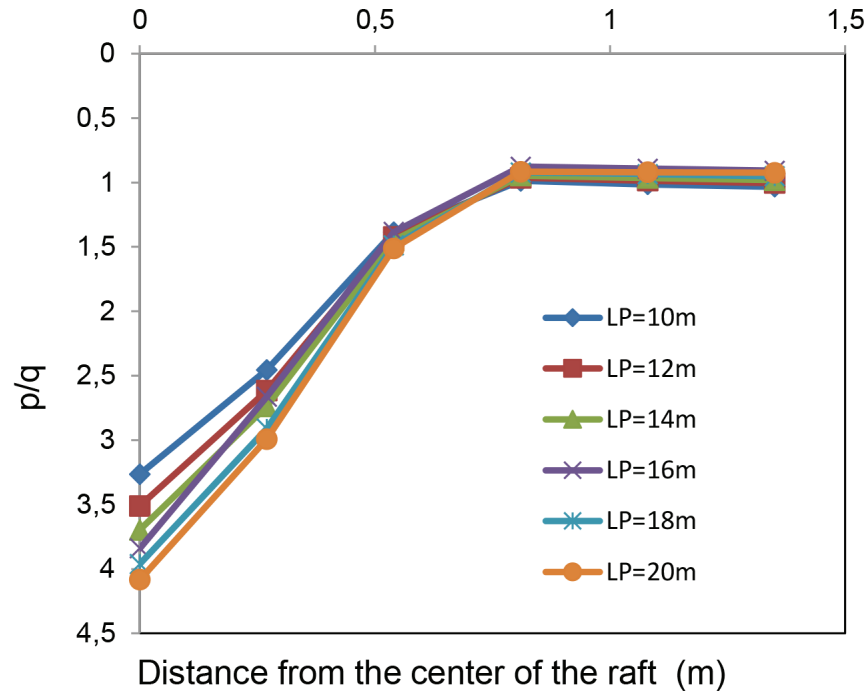

Fig. 14 Comparison of the normalized contact pressure along a raft for various lengths of the long pile.

The graph shown in Fig. 14 represents the normalized contact pressure along the raft for various lengths of the long pile, i.e., 10 $\mathrm{m}, 12 \mathrm{~m}, 14 \mathrm{~m}, 16 \mathrm{~m}, 18 \mathrm{~m}$ and $20 \mathrm{~m}$. It is clear that in all the cases the normalized contact pressure is at a maximum at the center and reduces towards the edge of the raft. Also, the p/q along the raft increases with an increase in the length of the long pile; however, the increase in the $\mathrm{p} / \mathrm{q}$ becomes almost constant with an increase in the pile's length beyond $16 \mathrm{~m}$. Initially, till a $16 \mathrm{~m}$-long pile length, the reactions developed are efficiently transferred to the raft by the subsoil; however, beyond $16 \mathrm{~m}$, the load is mainly carried by the long pile and dissipates beneath it.

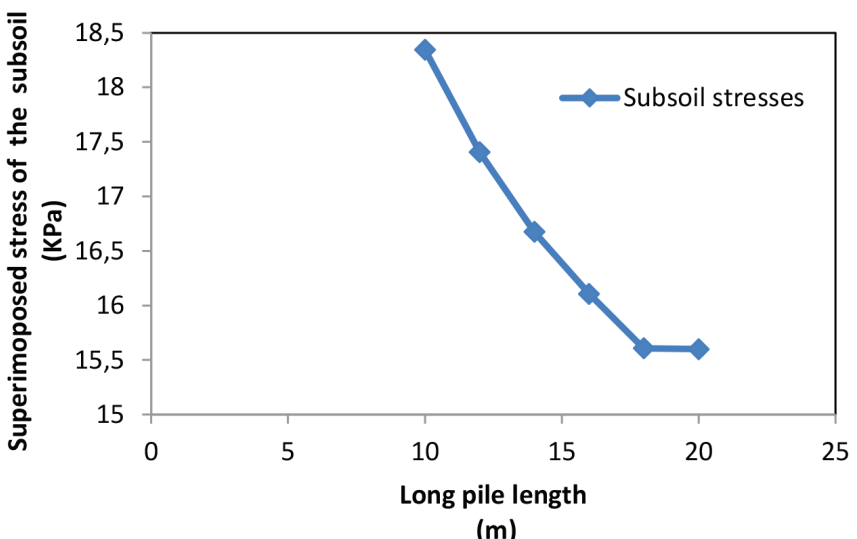

Fig. 15 Superimposed stresses of the subsoil for various lengths of the long pile.

Fig. 15 shows the variations in the superimposed stresses of the subsoil for different lengths of the long pile. The graph show that as the length of the long pile increases, the subsoil stresses decrease; however, the stresses become constant at a later stage, thus indicating that by further increasing the depth of the pile, the superimposed stresses taken by the subsoil remain constant. This further indicates that at a lower depth of the long pile, the bearing capacity of the subsoil can be utilized efficiently and that the stresses at the head of the long pile can be alleviated to a greater extent with the use of a cushion.

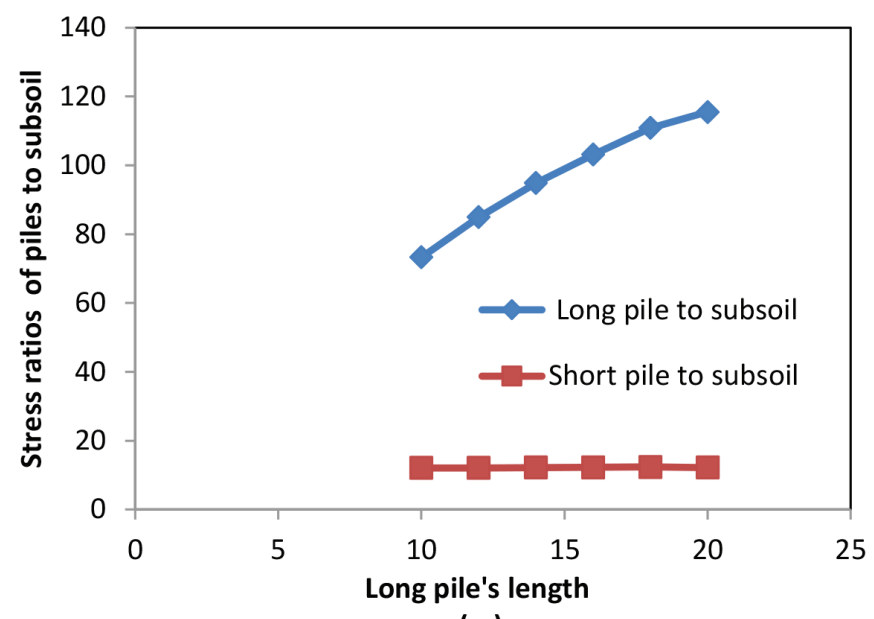

(m)

Fig. 16 Stress ratios of the piles to the subsoil for various lengths of the long pile.

Fig. 16 shows the stress ratios of the piles to the subsoil. The graph shows that as the depth of the long pile increases, the stress taken by the long pile increases; however, beyond a length of $16 \mathrm{~m}$, it almost becomes constant. In the case of the short piles, the stress distribution 
or load carried is almost constant; however, the short pile and the subsoil have come into the picture as their load-carrying capacity has been mobilized.

\subsection{Short pile modulus}

In the calculations, $\delta=0.3 \mathrm{~m}, \mathrm{Em}=80 \mathrm{MPa}, \mathrm{E}_{\mathrm{p}}=25000 \mathrm{MPa}$, and Esp varied from $60 \mathrm{MPa}, 100 \mathrm{MPa}, 200 \mathrm{MPa}$ and $2800 \mathrm{MPa}$. The $\mathrm{L}_{1}$ length of the long pile $=15 \mathrm{~m}, \mathrm{~L}_{2}=5.42 \mathrm{~m}$ is kept constant, and the other parameters are the same as the above.

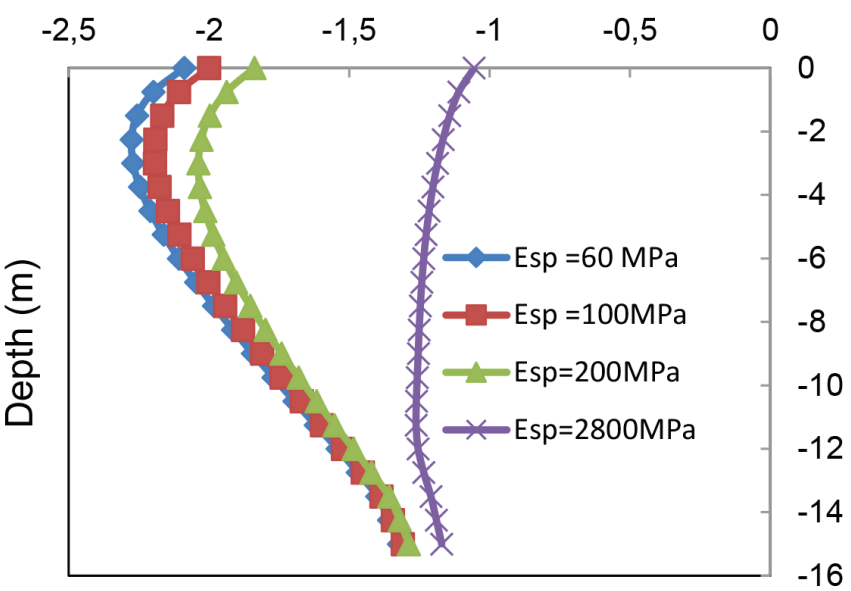

Axial stresses on the long pile (MPa)

Fig. 17 Comparison of the axial stress distributions along the depth of the long piles for various moduli of the short pile.

The above graph in Fig. 17 shows the axial stress distribution along a long pile for various moduli of the short piles, i.e., $60 \mathrm{MPa}$, $100 \mathrm{MPa}, 200 \mathrm{MPa}$ and $2800 \mathrm{MPa}$ respectively. In all the cases the maximum axial stress has been shifted from the head to a lower depth with the use of the cushion technique. Also, as the modulus of the short piles increases, the axial load carried by the long pile is reduced. Thus the load-carrying capacity of the short piles has increased by an increase in the modulus, which can be observed in Fig. 18.

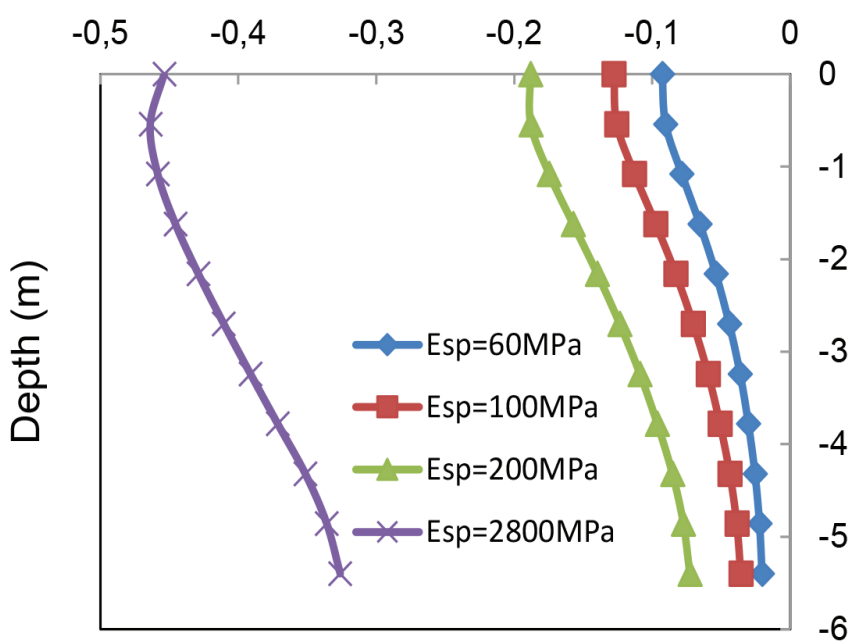

Axial stresses on the short piles (MPa)

Fig. 18 Comparison of the axial stress distributions along the depth of the short piles for various moduli of the short piles.
The axial stress concentration is addressed at a maximum at the head of the short piles, whereas for the long pile it has shifted to a lower depth; thus, it can be inferred that by applying the cushion technique, the load sharing has been evenly carried by mobilizing the load-carrying capacity of the short piles.

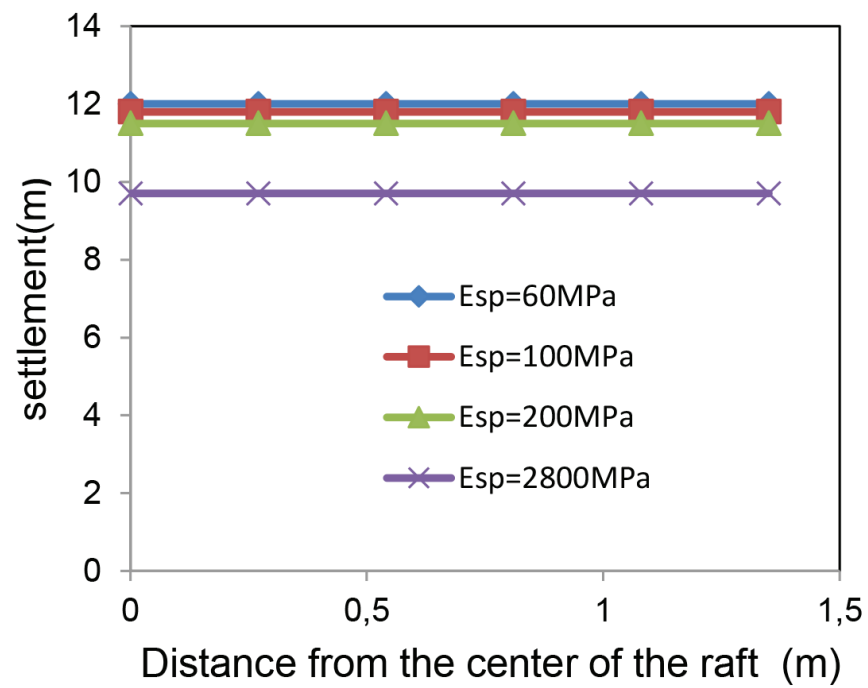

Fig. 19 Comparison of the settlement variations along the raft for varying moduli of the short piles.

The graph in Fig. 19 shows a comparison of the settlement along the raft for varying moduli of the short piles from $60 \mathrm{MPa}$ to $2800 \mathrm{MPa}$. It is clear that the settlement of the raft is at a maximum for Esp $=2800 \mathrm{MPa}$ and a minimum for Esp $=60 \mathrm{MPa}$; thus, the settlement of the raft can be reduced by using short piles with a higher modulus.

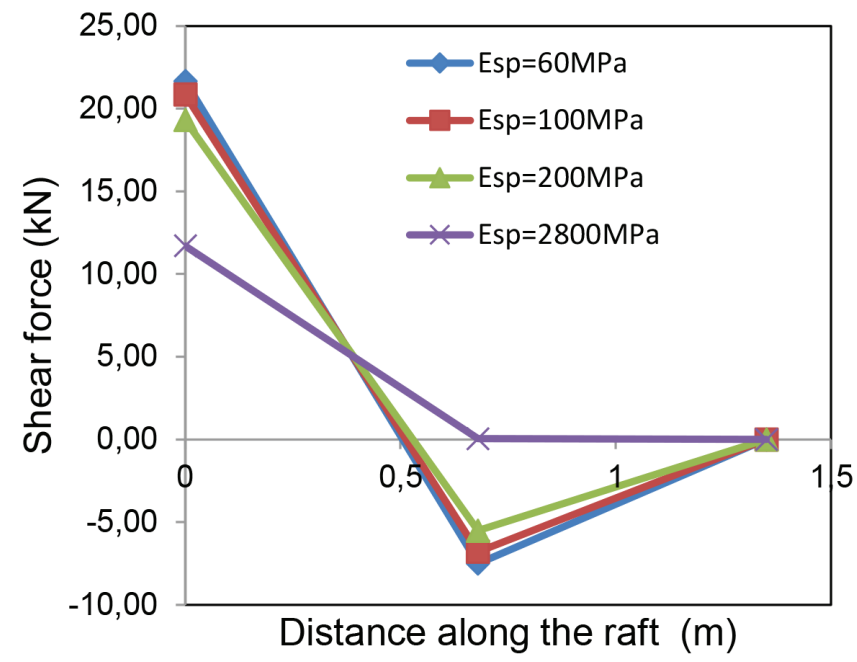

Fig. 20 Comparison of the shear force distributions along the raft for various moduli of the short piles.

The graph in Fig. 20 shows a comparison of the shear force distribution along the raft for various moduli of the short piles, i.e., 60 $\mathrm{MPa}, 100 \mathrm{MPa}, 200 \mathrm{MPa}$ and $2800 \mathrm{MPa}$, respectively. The graph shows that the shear force is at a minimum for a higher modulus of the short piles, i.e., $2800 \mathrm{MPa}$. As most of the load is carried by the short piles as the higher modulus value is reached, the reaction on the raft from the subsoil underneath it is reduced. 


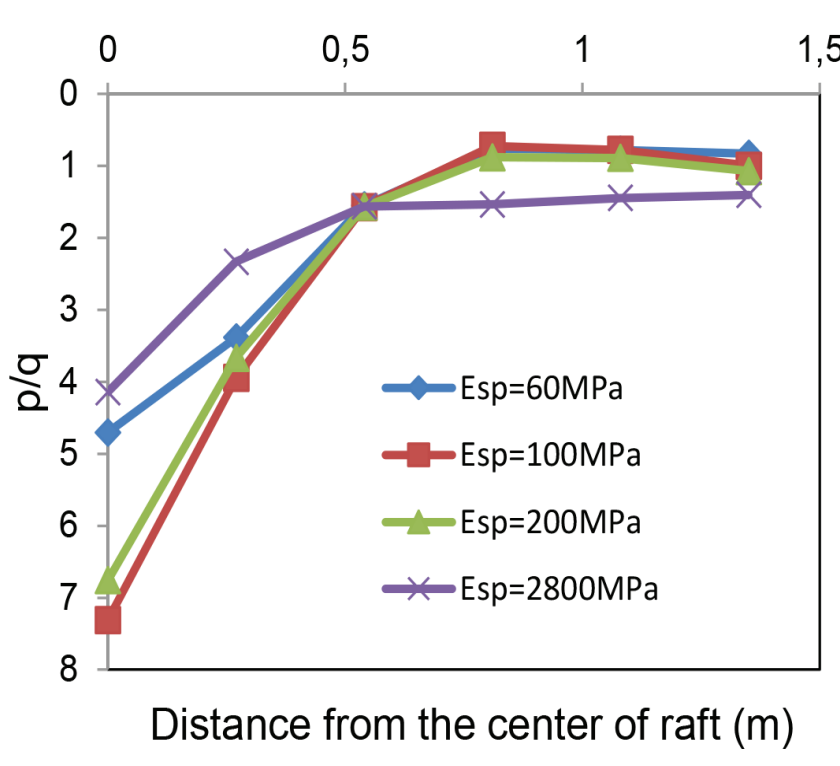

Fig. 21 Comparison of the normalized contact pressure along the raft for the various moduli of the short piles.

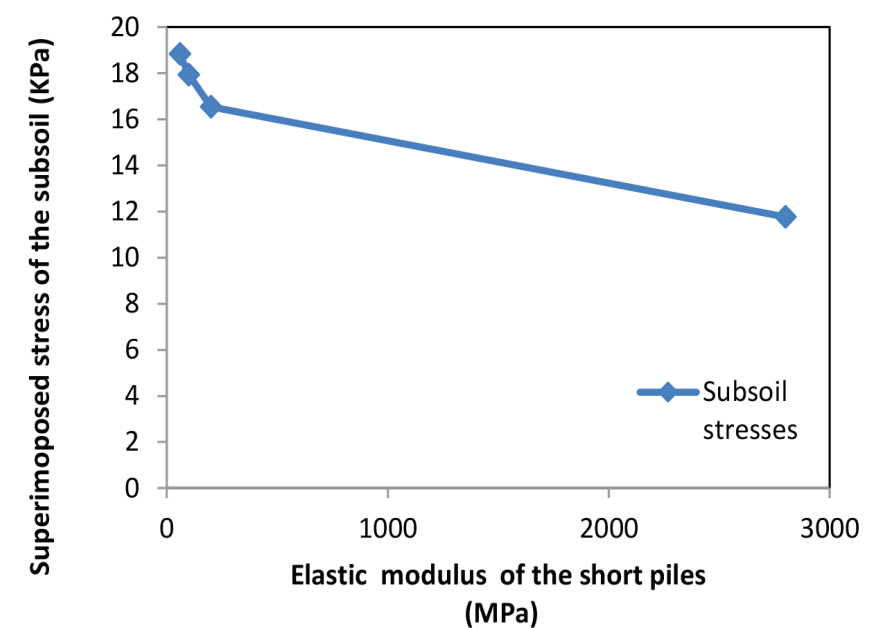

Fig. 22 Superimposed stresses of the subsoil for various moduli of the short pile.

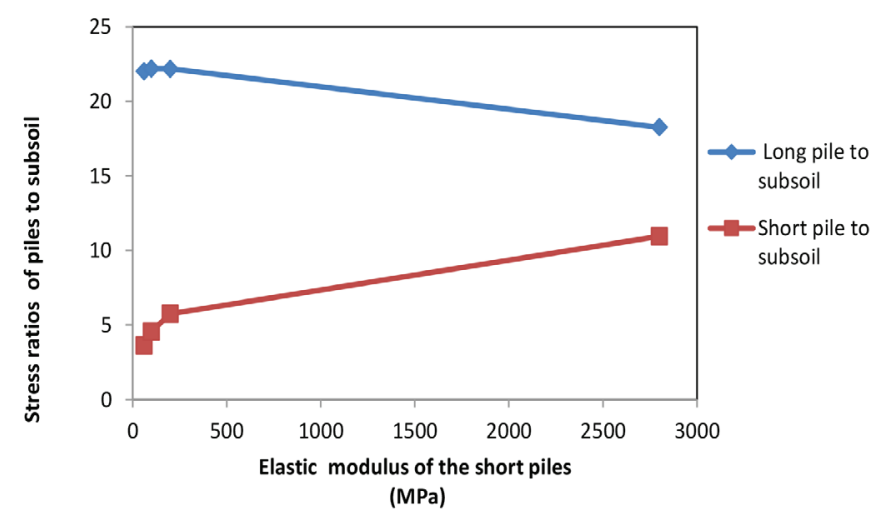

Fig. 23 Stress ratio of the piles to the subsoil for various moduli of the short piles.
The graph in Fig. 21 shows the normalized contact pressure along the raft for various moduli of the short piles, i.e., $60 \mathrm{MPa}, 100 \mathrm{MPa}$, $200 \mathrm{MPa}$, and $2800 \mathrm{MPa}$, respectively. It is clear that in all the cases, the normalized contact pressure is at a maximum at the center and reduces towards the edge of the raft. Also the $\mathrm{p} / \mathrm{q}$ along the raft increases with an increase in the modulus of the short piles; however, there is a reduction in the $\mathrm{p} / \mathrm{q}$ beyond a $100 \mathrm{MPa}$ modulus of the short piles.

Fig. 22 gives an exact idea of the superimposed stresses of the subsoil. It has been determined that as the modulus of the short piles increases, the subsoil stresses reduce; thus the stresses are predominantly carried by the short piles.

Fig. 23 provides the stress ratios of the long pile to the subsoil and the short piles to the subsoil. It can be seen that as the modulus of the short pile increases, the load is predominantly carried by the short piles, compared to the subsoil and the long pile, and is evenly adjusted with the use of the cushion technique. 


\section{SUMMARY AND CONCLUSIONS}

The following conclusions were derived from the parametric study considering the thickness of the raft, the long pile's length and the short pile's modulus:

1. With an increase in the thickness of the raft, the load-carrying capacity of the long pile and short piles reduces; thus it can be inferred that the axial load is mainly carried by the raft itself. The reductions in the load-carrying capacity of the long pile and short piles are $10 \%$ and $13 \%$, respectively.

2. The settlement of the raft reduces with an increase in the raft's thicknesses; thus, the reduction is $11 \%$. Also, the shear force distribution along the raft is reduced by $48 \%$ as the raft's thickness varies from $0.25 \mathrm{~m}$ to $2 \mathrm{~m}$. The normalized contact pressure along the raft increases at the centre of the raft till the raft's thickness is $0.75 \mathrm{~m}$ and becomes constant for $1 \mathrm{~m}$ and reduces for a $2 \mathrm{~m}$ raft thickness. Thus it can be deduced from the current study that the optimum thickness of a raft should be around $0.75 \mathrm{~m}$.

3. As the length of the long pile increases, the axial load capacity at the head of the long pile increases; however, beyond a $16 \mathrm{~m}$ length of the long pile the increment in the load capacity is less; thus, the percentage increase is $34 \%$ as the length varies from $10 \mathrm{~m}$ to $20 \mathrm{~m}$.

4. In the case of the short piles, the axial load-carrying capacity decreases with an increase in the length of the long pile; however, beyond a $16 \mathrm{~m}$ length of the long pile, the decrease in the axial load capacity is less. The percentage reduction in the load-carrying capacity of the short pile is $14 \%$. It was observed that the load concentration at the head of the long pile shifted to a lower depth, whereas the stress concentrations at the head of the short piles were at a maximum; thus, with the inclusion of the cushion, the load adjustment was evenly done among the piles by making proper use of the load-bearing capacity of the flexible short piles.
5. The settlement of the raft reduces with an increase in the length of the long piles; thus, the reduction was $20 \%$. Also, the shear force distribution along the raft initially increases by $88 \%$ till $16 \mathrm{~m}$; however, with any further increase it reduces and become almost constant. Similarly, the normalized contact pressure along the raft increased at the center of the raft by $25 \%$ with an increase in the long pile's length; however, it reduces near the edge of the raft in all the cases. For the current study the optimum length obtained of the long pile is $16 \mathrm{~m}$.

6. As the modulus of the short pile increases from $60 \mathrm{MPa}$ to $2800 \mathrm{MPa}$, the load-carrying capacity of the long pile decreases and the short pile increases by $49 \%$ to $390 \%$ respectively.

7. The settlement of the raft reduces with an increase in the modulus of the short piles; thus, the reduction is $19 \%$. The shear force distribution along the raft reduces by $46 \%$ as the Esp varies from $60 \mathrm{MPa}$ to $2800 \mathrm{MPa}$. The normalized contact pressure along the raft initially increases with an increase in Esp; however as the modulus of the short piles reaches its maximum value, the load is predominantly carried by the short piles; thus, the $\mathrm{p} / \mathrm{q}$ decreases at the center for a higher value, i.e., $E s p=2800 \mathrm{MPa}$. However, the higher value of the short pile's modulus is applicable for higher design loads or to improve a worse subsoil condition, i.e., in the case of marine clay or liquefiable soil. Thus from the current study it should be concluded that Esp $=200 \mathrm{MPa}$ is the optimum short pile modulus that can be used under residential buildings. 


\section{REFERENCES}

Baziar, M. H. - Ghorbani, A. - Katzenbach, R. (2009) Small-Scale Model Test and Three-Dimensional Analysis of Pile-Raft Foundation on Medium-Dense Sand. International Journal of Civil Engineering. Vol. 7, No. 3, pp. $170-175$.

Eslami, A. - SalehiMalekshah, S. (2011) Analysis of non-connected piled raft foundations (NCPRF) with cushion by finite element method. Comp. Meth. Civil Eng., Vol. 2, No. 2, pp. 153 - 168.

Kaifu, L. - Xinyu, X. - Shangwei, S. - Xiangrong, Z. (2009) Numerical Analysis on the Performance of a Cushioned Foundation with a Mixture of both Rigid and Flexible Piles. Proceedings of Advances in ground improvement: Research to practise in the United States and China, US-China Workshop on Ground Improvement Technologies, pp. $102-111$.

Lee, C. J. - Bolton, M. D. - Al-Tabbaa, A. (2002) Numerical modelling of group effects on the distribution of dragloads in pile foundations. Geotechnique, Vol. 52, No. 5, pp. $325-335$.

Liang, F. Y. - Chen, L. Z. - Shi, X. G. (2003) Numerical analysis of composite piled raft with cushion subjected to vertical load. Computers and Geotechnics, Vol. 30, pp. $443-453$.
Midas (2012) Midas GTS 2012. Analysis user manual Version 2.2.

Ottaviani, M. (1975) Three-dimensional finite element analysis of vertically loaded pile groups. Geotechnique, Vol. 25, No. 2, pp. $159-174$.

Poulos, H. G. (2001) Piled raft foundations: design and applications. Geotechnique, Vol. 51, No. 2, pp. 95 - 113

Randolph, M. F. - Wroth, C. P. (1981) Application of the failure state in undrained simple shear to the shaft capacity of driven piles. Geotechnique, Vol. 31, No. 1, pp. $143-157$.

Soil investigation report (1995) on foundation on Urea Plant Kribhco unit-III Surat by unique testing and advisory services.

Soil investigation report (2009) for forging shop at $L \& T$ Limited. West Hazira complex, Surat district.

Zheng, J. J. - Abusharar, S. W. - Wang, X. Z. (2008) Three-dimensional nonlinear finite element modeling of composite foundation formed by CFG-lime piles. Computers and Geotechnics, Vol. 35, pp. $637-643$ 